\title{
Resistance to Anticarsia gemmatalis Hübner (Lepidoptera, Noctuidae) in transgenic soybean (Glycine max (L.) Merrill Fabales, Fabaceae) cultivar IAS5 expressing a modified Cry1Ac endotoxin
}

\author{
Milena Schenkel Homrich ${ }^{1}$, Luciane Maria Pereira Passaglia ${ }^{1}$, Jorge Fernando Pereira ${ }^{2}$, \\ Paulo Fernando Bertagnolli ${ }^{2}$, Giancarlo Pasquali ${ }^{3}$, Mohsin Abbas Zaidi ${ }^{4}$, Illimar Altosaar ${ }^{4}$ \\ and Maria Helena Bodanese-Zanettini ${ }^{1}$ \\ ${ }^{I}$ Departamento de Genética, Instituto de Biociências, Universidade Federal do Rio Grande do Sul, \\ Porto Alegre, RS, Brazil. \\ ${ }^{2}$ Centro Nacional de Pesquisa de Trigo, EMBRAPA, Passo Fundo, RS, Brazil. \\ ${ }^{3}$ Departamento de Biologia Molecular e Biotecnologia, Instituto de Biociências, \\ Universidade Federal do Rio Grande do Sul, Porto Alegre, RS, Brazil. \\ ${ }^{4}$ Biochemistry, Microbiology and Immunology Department, University of Ottawa, Ottawa Ontario, Canada.
}

\begin{abstract}
Somatic embryos of the commercial soybean (Glycine max) cultivar IAS5 were co-transformed using particle bombardment with a synthetic form of the Bacillus thuringiensis delta-endotoxin crystal protein gene cry $1 A c$, the $\beta$-glucuronidase reporter gene gusA and the hygromycin resistance gene hpt. Hygromycin-resistant tissues were proliferated individually to give rise to nine sets of clones corresponding to independent transformation events. The co-bombardment resulted in a co-transformation efficiency of $44 \%$. Many histodifferentiated embryos and 30 well-developed plants were obtained. Twenty of these plants flowered and fourteen set seeds. The integration and expression of the cry $1 A c$, gusA and $h p t$ transgenes into the genomes of a sample of transformed embryos and all $\mathrm{T}_{0}$, $\mathrm{T}_{1}, \mathrm{~T}_{2}$ and $\mathrm{T}_{3}$ plants were confirmed by Gus activity, PCR, Southern and western blot, and ELISA techniques. Two $\mathrm{T}_{0}$ plants out of the seven co-transformed plants produced seeds and were analyzed for patterns of integration and inheritance until the $\mathrm{T}_{3}$ generation. Bioassays indicated that the transgenic plants were highly toxic to the velvetbean caterpillar Anticarsia gemmatalis, thus offering a potential for effective insect resistance in soybean.
\end{abstract}

Key words: Anticarsia gemmatalis, crylAc gene, IAS5 cultivar, insect resistance, transgenic soybean.

Received: July 10, 2007; Accepted: November 8, 2007.

\section{Introduction}

Soybean (Glycine $\max$ (L.) Merrill Fabales, Fabaceae) is one of the most important sources of edible oil and protein, resulting in special interest in the genetic improvement of this crop. The velvetbean caterpillar (Anticarsia gemmatalis Hübner) is a major soybean pest, mainly occurring in soybean growing regions of North and South America (Panizzi and Corrêa-Ferreira, 1997; Macrae et al., 2005), causes extremely high levels of defoliation when infestation is heavy and can severely damage axillary meristems, with a single caterpillar being able to consume up to $110 \mathrm{~cm}^{2}$ of soybean foliage (Walker et al.,

Send correspondence to Maria Helena Bodanese-Zanettini Departamento de Genética, Instituto de Biociências, Universidade Federal do Rio Grande do Sul, Caixa Postal 15053, 91501-970, Porto Alegre, RS, Brazil. E-mail: maria.zanettini@ufrgs.br.
2000). However, various authors have reported that $A$. gemmatalis can be controlled by the delta-endotoxin ( $\delta$-endotoxin) produced by some strains of Bacillus thuringiensis (Stewart et al.,1996; Walker et al., 2000; Macrae et al., 2005).

Various DNA delivery methods and plant tissues have been used in developing transgenic soybean plants. Such techniques include particle bombardment of shoot meristems (McCabe et al., 1988; Christou et al., 1989), embryogenic suspension cultures (Finer and McMullen, 1991; Stewart et al., 1996) and Agrobacterium tumefaciens-mediated T-DNA delivery into cotyledonary nodes derived from five-day to seven-day old seedlings (Donaldson and Simmonds, 2000; Olhoft et al., 2003), mature seeds (Paz et al., 2006), immature zygotic cotyledons (Yan et al., 2000), somatic embryos derived from immature 
cotyledons (Parrott et al., 1989) or embryogenic suspension cultures (Trick and Finer, 1998).

A simple procedure for the establishment and proliferation of somatic embryos from immature cotyledons, more rapid and less labor-intensive than embryogenic suspension cultures, was developed by Santarém et al. (1997), using a semi-solid medium described by Wright et al. (1991). Using this procedure transgenic soybean plants have been generated from the soybean cultivars Jack (Santarém and Finer, 1999) and IAS5 (Droste et al., 2002) expressing the $\beta$-glucuronidase (Gus, EC 3.2.1.31) reporter gene gusA. The transgenic plants obtained in both of these studies were fertile, indicating that this strategy is a promising tool for the recovery of transgenic soybean plants.

Earlier studies have indicated that soybean regeneration is genotype-specific with differences in their responses to in vitro culture and transformation. There is no efficient transformation system for a wide range of soybean cultivars (Hofmann et al., 2004; Ko et al., 2004), which explains why very few reports on genetic transformation of commercial soybean cultivars are available. According to Meurer et al. (2001) there are two major routes to improve embryogenic culture-based soybean regeneration and transformation protocols with the goal of increasing the recovery of transgenic fertile lines. One option is to screen large numbers of new soybean cultivars and genotypes for embryogenic potential, while another option is to use existing protocols and cultivars, such as the Jack cultivar, coupled with traditional breeding programs for introgressing transgenic traits into other genotypes. The second option was followed by Stewart et al. (1996) to introduce insect resistance traits into soybean and Yan et al. (2000) for engineering soybean protein modification.

The Brazilian soybean cultivar IAS5 has commonly been used in genetic improvement programs and recommended by the Brazilian Agricultural Ministry (Ministério da Agricultura, Pecuária e Abastecimento, MAPA) for commercial growing in the Brazilian states of Goiás, Minas Gerais, Paraná, São Paulo and Rio Grande do Sul (MAPA, 2007). This cultivar has shown good reliable response in embryogenic systems (Santos et al., 1997; Droste et al., 2002).

The study described in this paper was aimed at developing transgenic soybean with resistance to $A$. gemmatalis larvae. Somatic embryos of the IAS5 cultivar growing on semi-solid medium were transformed with a synthetic $B a$ cillus thuringiensis $\delta$-endotoxin crystal protein $c r y 1 A c$ gene by particle bombardment and the $c r y 1 A c$ transgene insertion pattern in the transgenic plants analyzed in the primary transformants. Transmission and expression of the transgenes were also characterized in the $T_{1}, T_{2}$ and $T_{3}$ generations. Insect feeding assays indicated that the transgenic plants were highly toxic to A. gemmatalis larvae.

\section{Materials and Methods}

\section{Plant material and plasmids used for soybean transformation}

In the experiments described in this paper we started with seeds of Glycine max cultivar IAS5 supplied by Embrapa Soja, Londrina, PR, Brazil. Pods containing immature seeds $3-5 \mathrm{~mm}$ in length were harvested from fieldgrown plants. Somatic embryogenesis from immature cotyledons was induced, proliferated and maintained as described by Droste et al. (2002).

The two plant transformation vector plasmids used were: pGusHyg, a pUC18 derivative carrying gus $A$ and the hygromycin resistance gene $h p t$, both driven by the cauliflower mosaic virus (CaMV) 35S promoter with a nopaline synthase gene (nos) terminator; and pGEM4Z-Cry1Ac, a pGEM4Z derivative containing the truncated synthetic crylAc gene under control of the cauliflower mosaic virus (CaMV) 35S promoter with a nos terminator. The crylAc used in this study was synthesized at the University of Ottawa using the recursive polymerase chain reaction (PCR) approach (Prodromou and Pearl, 1992). The original bacterial $c r y 1 A c$ has a $\mathrm{G}+\mathrm{C}$ content of $37 \%$ while the synthetic version was designed with a $\mathrm{G}+\mathrm{C}$ content of $47.7 \%$ for expression in dicotyledonous plants, with the overall modifications resulting in higher Cry1Ac expression levels in transgenic plants (Sardana et al., 1996).

\section{Transformation and regeneration of transgenic plants}

Embryogenic tissue from immature cotyledons of soybean cultivar IAS5 was transformed by particle bombardment using the particle inflow gun (PIG; Finer et al., 1992) as described by Droste et al. (2002). Briefly, 20 embryogenic clusters, equivalent to about $70 \mathrm{mg}$ of tissue, were placed in a petri dish containing D20 medium (Wright et al., 1991) and bombarded once with M10 tungsten particles (Dupont, USA) coated with a 4:1 molar ratio of pGEM4Z-Cry1Ac (4 $\left.\mu \mathrm{g} \mu \mathrm{L}^{-1}\right)$ to pGusHyg $\left(1 \mu \mathrm{g} \mu \mathrm{L}^{-1}\right)$ plasmid DNA. This procedure was repeated to produce 15 replicate plates. The bombarded tissue was cultured for 14 days on D20 medium containing $12.5 \mathrm{mg} \mathrm{L}^{-1}$ of the selective agent hygromycin-B, after which the tissue was cultured for three months on the same medium containing $25 \mathrm{mg} \mathrm{L}^{-1}$ hygromycin-B. For the establishment and proliferation of embryogenic tissues after selection pieces of green tissue were subcultured every 14 days for 56 days in plates containing fresh D20 medium without antibiotics.

Three months after bombardment, hygromycin-resistant embryogenic soybean tissues were visually selected, counted and separately cultured for the establishment and proliferation of lines corresponding to putative independent transformation events. Out of 60 independent pieces of hygromycin-resistant tissues we established nine proliferative lines. Lines 18 and 43 subsequently being shown to 
consist of plants resulting from two different transformation events so that these lines were sub-divided into ' $a$ ' and 'b' plants. Different plants from the same line were categorized as 'families', with, for example 18a1 being plant 1 from line 18a. To stimulate histodifferentiation, clusters of hygromycin-resistant embryos were transferred to plates containing MSM6 maturation medium (Finer and McMullen, 1991) for 60 days.

The histodifferentiated somatic embryos were transferred to MS0 conversion medium, containing Murashige and Skoog (MS) salts solution (Murashige and Skoog, 1962), B5 vitamins solution (Gamborg et al., 1968), 3\% (w/v) sucrose, $0.3 \%$ (w/v) Phytagel (Sigma, USA), pH 6.4. After a further 20-30 days the germinated embryos were individually transferred from the petri plates to $100 \mathrm{~mL}$ flasks containing $25 \mathrm{~mL}$ of the same medium to continue regeneration of the plantlets.

After about 30-40 days in the flasks the regenerated plantlets were transferred to vermiculite contained in plastic cups covered with polyvinyl chloride film in which the remained for a further 30 days during which time they were gradually exposed to ambient levels of relative humidity $(\mathrm{RH} \approx 50 \%)$. After that, plants were transferred to pots containing $1 \mathrm{~kg}$ of soil and maintained at $26{ }^{\circ} \mathrm{C} \pm 3{ }^{\circ} \mathrm{C}$ $(\mathrm{RH} \approx 80 \%)$ in a growth chamber under a $14 \mathrm{~h}$ photoperiod and a light intensity of 13,500 lux provided by $60 \mathrm{~W}$ daylight type fluorescent lamps (Osram, Brazil). The plants remained in these pots until physiological maturity ( $\approx 150$ days). These plants were the primary transgenic regenerants $\left(\mathrm{T}_{0}\right)$, i.e., transgenic plants recovered from the explant originally subjected to particle bombardment. Thirty well-developed plantlets were transplanted ex vitro, of which 20 reached maturity and flowered and 14 set seeds. All embryos/plants derived from an independent piece of hygromycin-resistant tissue were noted as being clonal embryos/plants.

For progeny analysis the $T_{1}$ seeds, equivalent to the $F_{1}$ seeds for non-transgenic plants, obtained from selfpollination of $\mathrm{T}_{0}$ plants were planted in pots containing $8 \mathrm{~kg}$ of soil fertilized with an equivalent of $500 \mathrm{~kg} / \mathrm{ha}$ of $0-25-25$ (N-P-K) and $6 \mathrm{t} /$ ha lime. The seeds were sown in December 2004 and harvested in April 2005, in a greenhouse, under natural light at $25 \pm 5{ }^{\circ} \mathrm{C}$, relative humidity of about $50 \% \pm 10 \%$, and a photoperiod varying from $14 \mathrm{~h}$ in December to $12 \mathrm{~h}$ in April. Plants were grown until physiological seed maturity. The $T_{1}$ plants were saved to produce the $\mathrm{T}_{2}$ generation which was in turn grown to maturity under the same conditions as their parents and saved to produce the $\mathrm{T}_{3}$ generation. The chi-square $\left(\chi^{2}\right)$ test was used to confirm the expected Mendelian segregation patterns of 3:1 and 2:1 (transgenic: non-transgenic plants). Some $T_{3}$ plants were reciprocally crossed to non-transgenic plants. Ten plants of the 18a1 family were used as the pollen donor and 10 as the pollen recipient. Twenty-five plants of $18 \mathrm{a} 4$ fam- ily were crossed as pollen recipient. Ten flowers were pollinated per plant.

We also investigated the number of homozygous plants positive for both Cry1Ac and GusA. A $\mathrm{T}_{3}$ transformant plant from the $18 \mathrm{a} 4$ family that served as the pollen recipient in the backcross set four seeds which gave raise to four plants positive for both Cry1 Ac and GusA, indicating that this $\mathrm{T}_{3}$ transformant plant was homozygous. To check this we tested 20 seeds obtained from self-pollination of the $\mathrm{T}_{3}$ transformant plant, which were germinated on wet filter paper to produce seedlings which we analyzed for Gus activity and crylAc expression. We also used this methodology, and the same number of selfed seeds for each plant, to investigate the possible homozygous nature of 253 out of the $309 \mathrm{~T}_{3}$ plants positive for both Cry1Ac and GusA.

\section{PCR analysis and Southern blot hybridization of digested genomic DNA}

We used the cetyltrimethylammonium bromide (CTAB) procedure (Doyle and Doyle, 1987), with some modifications, to extract genomic DNA from 72 of the histodifferentiated soybean embryos and leaf tissues of all of the 20 soybean plants which reached maturity. The extracted DNA samples were individually assayed for the presence of crylAc, gusA and hpt. The PCR primers used to detect $c r y 1 A c$ were $c r y$ FOR (5'GGGGATCCATGGATA ACAATCCGAAC3') and cryREV (5'CAGTCGACATT CAGCCTCGAGTGTTG3'), which amplify a 1845 bp region of $c r y l A c$. The reaction mixture $(25 \mu \mathrm{L})$ consisted of $200 \mu \mathrm{M}$ dNTPs, 1 unit of Taq DNA polymerase (Invitrogen), $1 \mathrm{X}$ Reaction buffer with $2 \mathrm{mM} \mathrm{MgCl} 2,100 \mathrm{nM}$ of each primer and $100 \mathrm{ng}$ of each DNA sample. Amplifications were carried out by pre-cycling at $94^{\circ} \mathrm{C}$ for $5 \mathrm{~min}$, followed by 30 cycles of $94{ }^{\circ} \mathrm{C}$ for $1 \mathrm{~min}, 52^{\circ} \mathrm{C}$ for $1 \mathrm{~min}$ and $72{ }^{\circ} \mathrm{C}$ for $2 \mathrm{~min}$, with a final extension step of $5 \mathrm{~min}$ at $72{ }^{\circ} \mathrm{C}$. The PCR primers used to $\operatorname{detect}$ gus $A$ were gusAFOR (5'GGTGGGAAAGCGCGTTACAAG3') and gusAREV (5'GGATTCCGGCATAGTTAAAGG3') amplifying $622 \mathrm{bp}$, while to detect $h p t$ we used $h p t \mathrm{FOR}\left(5^{\prime} \mathrm{GC}\right.$ GATTGCTGATCCCCATGTGTAT3') and $h p t \mathrm{REV}$ (5'G GTTTCCACTATCGGCGAGTACTT3') which amplify $512 \mathrm{bp}$. The reaction mixtures for both genes were as described above while the amplification conditions for both these genes consisted of pre-cycling at $94{ }^{\circ} \mathrm{C}$ for $5 \mathrm{~min}$, followed by 30 cycles of $94{ }^{\circ} \mathrm{C}$ for $45 \mathrm{~s}, 52{ }^{\circ} \mathrm{C}$ for $45 \mathrm{~s}$ and $72{ }^{\circ} \mathrm{C}$ for $45 \mathrm{~s}$, with a final extension of $2 \mathrm{~min}$ at $72^{\circ} \mathrm{C}$. All amplifications reactions were carried out in a PCR Express Thermal Cycler (Thermo Hybaid, UK). After amplification the products were separated by electrophoreses on $1 \%$ (w/v) agarose gel and transferred overnight onto Hybond $\mathrm{N}+$ membranes (GE Healthcare) for the Southern blot procedure following standard protocols (Sambrook and Russel, 2001). Probe labeling, hybridization, stringency washes and detection were carried out as specified by the ECL kit (GE Healthcare). The DNA blotting was probed 
with a $1.8 \mathrm{~kb}$ PCR fragment containing the $c r y l A c$ coding sequence purified from agarose gel using the GFX kit (GE Healthcare). Hybridizing bands were detected by exposure to Kodak X-OMAT autoradiography films for $2 \mathrm{~h}$.

The Southern blot hybridization of digested genomic DNA was carried out using $20 \mu \mathrm{g}$ of total genomic DNA from putative transgenic and non-transgenic control plants digested overnight at $37{ }^{\circ} \mathrm{C}$ with the restriction enzymes BamHI, KpnI and SalI (Promega, USA). Digested genomic DNA of each plant was separated by electrophoresis on $0.8 \%(\mathrm{w} / \mathrm{v})$ agarose gel and transferred from the gel to a Hybond $\mathrm{N}+$ nylon membrane. Probe labeling, hybridization, stringency, washes and detection were carried out as specified above.

\section{Gus histochemical assay and protein expression analysis}

Leaf disks or seedlings were assayed for Gus activity using the improved histochemical staining protocol (Jefferson, 1987).

For protein expression analysis $0.2 \mathrm{~g}$ of fresh leaf tissue was excised from $\mathrm{T}_{0}$ plants and homogenized in $500 \mu \mathrm{L}$ of extraction buffer [containing $50 \mathrm{mM}$ of $1 \mathrm{M}$ Tris- $\mathrm{HCl}$ $(\mathrm{pH} 6.8), 0.2 \%(\mathrm{w} / \mathrm{v})$ polyvinylpyrrolidone (PVP-40, Sigma) and $1 \%$ (v/v) $\beta$-mercaptoethanol (Sigma)]. Samples were stirred for $30 \mathrm{~min}$ at $4{ }^{\circ} \mathrm{C}$ and then clarified by centrifugation at $10,000 \mathrm{~g}$. Protein concentration was determined by the Bradford method (Bradford, 1976) with bovine serum albumin as protein standard. For each plant, $50 \mu \mathrm{g}$ of crude protein extract was subjected to $10 \%(\mathrm{w} / \mathrm{v})$ sodium dodecyl sulfate-polyacrylamide gel electrophoresis (SDS-PAGE) and transferred to a nitrocellulose membrane. The presence of the Cry1Ac protein was detected using polyclonal antibody specific for Cry1Ac $\delta$-endotoxin from Bacillus thuringiensis (kindly supplied by Dr. Lidia Mariana Fiuza, UNISINOS, RS, Brazil). The protein bands were visualized using the ECL Western Blot Detection and Analysis System (GE Healthcare). Detection of Cry1Ac protein produced by $T_{1}, T_{2}$ and $T_{3}$ plants was monitored by a double-sandwich enzyme-linked immunosorbent assay (ELISA) procedure using the Trait Check Bt $1 \mathrm{Ac}$ cotton leaf/seed kits (Strategic Diagnostics Inc., USA).

\section{Insect bioassays}

Insecticidal activity of $\mathrm{T}_{2}$ transgenic plants toward $A$. gemmatalis larvae was evaluated using a detached leaffeeding assay. The plants were heterozygous for $c r y l A c$ as determined by segregation analysis and were CrylAcpositive as ascertained by double-sandwich ELISA. Leaflets from large trifoliate leaves were placed in $100 \mathrm{~mm} \mathrm{x}$ $20 \mathrm{~mm}$ petri dishes containing a $90 \mathrm{~mm}$ Whatman $\mathrm{n}$. 1 filter paper (Whatman International, UK) saturated with distilled water to maintain high humidity. The amount of leaf tissue was kept as uniform as possible from one dish to another. Leaf samples were infested with 20 neonate $A$. gemmatalis larvae per plate. We used 10 transgenic plants from the $18 \mathrm{a} 1$ family and 30 from the $18 \mathrm{a} 4$ family with four replicate plates per plant, were included in the bioassay. Three non-transgenic IAS5 plants of the same age as the transgenic plants, with four replicate plates per plant, were used as controls. After $24 \mathrm{~h}$, the percent foliage consumption was estimated. Remaining leaf remnants were removed and replaced by a $1 \mathrm{~cm}^{3}$ of a solid artificial diet (Greene et al., 1976). Leaf consumption percentages were converted to scores as follows: $0=$ no consumption, $1=$ less than $50 \%$; $2=$ more than $50 \%$; and $3=100 \%$ consumption. The number of dead larvae and alive larvae was determined $24 \mathrm{~h}$, $48 \mathrm{~h}, 72 \mathrm{~h}$ and $96 \mathrm{~h}$ after the start of the assay.

\section{Results and Discussion}

\section{Transformation and regeneration of transgenic plants}

From the 60 independent pieces of hygromycinresistant tissue we obtained nine proliferative lines from which 613 histodifferentiated somatic embryos were transferred to conversion medium. In the later stages of the experiment, 30 well-developed plantlets were transplanted $e x$ vitro, 20 of which reached maturity and flowered and 14 of these set seeds. All embryos/plants derived from an independent piece of hygromycin-resistant tissue were noted as being clonal embryos or plants.

\section{Transgene integration and expression}

We used PCR to screen 72 histodifferentiated embryos and the 20 plants which reached maturity for the presence of crylAc, gusA and hpt. Two of the 9 lines (22\%) produced no PCR products for any of the genes tested and were considered "escapes" and discarded. The molecular analysis also showed that one piece of hygromycinresistant tissue could contain two independent transformation events, base on which lines 18 and 43 were subdivided ( $a$ and $b$ ).

The molecular characterization of transformed lines is presented in Table 1. All 64 embryos and 11 plants of the nine independent lines presented the expected 622 bp gus $A$ fragment and the $512 \mathrm{bp} \mathrm{hpt} \mathrm{fragment.} \mathrm{The} \mathrm{presence} \mathrm{of} \mathrm{the}$ expected $1845 \mathrm{bp}$ cry $1 A c$ fragment was observed in $23 \mathrm{em}-$ bryos and seven plants derived from four lines (18a, 26, 41 and 43a). Simultaneous occurrence of gus A, hpt and crylAc genes in these four lines allowed the co-transformation efficiency to be calculated $(4 / 9=44 \%)$. The efficiency of our transformation rate is similar to that previously reported for soybean, since in situations in which two genes on independent plasmids have been introduced by particle bombardment the co-transformation rates have been shown to vary from 18\% to 50\% (Christou and Swain, 1990; Li et al., 2004).

Western blot hybridization was used to evaluate the expression of crylAc gene at the protein level. When the 
Table 1 - Polymerase chain reaction (PCR) characterization of transgenic soybean histodifferentiated embryos and recovered plants derived from independent transformation events (lines). The genes analyzed were the Bacillus thuringiensis endotoxin gene crylAc, the $\beta$-glucuronidase reporter gene gusA and the hygromycin resistance gene $h p t$.

\begin{tabular}{lccccc}
\hline & \multicolumn{2}{c}{ Number analyzed } & & \multicolumn{2}{c}{ PCR analysis results } \\
\cline { 2 - 3 } \cline { 5 - 6 } Lines & Embryos & Plants & & crylAc & gus A and $h p t$ \\
\hline 4 & 11 & 0 & & - & + \\
5 & 10 & 0 & & - & + \\
$18 \mathrm{a}$ & 2 & 4 & & + & + \\
$18 \mathrm{~b}$ & 6 & 1 & & - & + \\
19 & 11 & 3 & & - & + \\
26 & 9 & 1 & & + & + \\
41 & 4 & 2 & & + & + \\
$43 \mathrm{a}$ & 8 & 0 & & + & + \\
$43 \mathrm{~b}$ & 3 & 0 & & - & + \\
For all nine lines & 64 & 11 & & 4 & + \\
\hline
\end{tabular}

proteins were separated electrophoretically on SDS gel, a band of $\approx 70 \mathrm{kDa}$ corresponding to the Cry1Ac toxin was detected in plants which were positive for crylAc and gus A (Figure 1) but no antibody reactive protein was detected in plants which were negative for crylAc and positive for gusA or in non-transgenic plants.

\section{Transgene segregation}

We obtained seven co-transformed $\mathrm{T}_{0}$ plants containing the crylAc, gusA and hpt genes but only plants $18 \mathrm{a} 1$ and $18 \mathrm{a} 4$, derived from the same 18a line (Table 1), produced seeds and were analyzed for patterns of integration and inheritance until the $\mathrm{T}_{3}$ generation. Expression of the crylAc gene in the $\mathrm{T}_{1}$ and $\mathrm{T}_{2}$ plants was first determined using the double-sandwich antibody procedure and Gus expression by histochemically assaying discs from young leaves. To validate the results of the preliminary tests, the presence of transgenes were confirmed by PCR analysis in all $\mathrm{T}_{1}$ and $\mathrm{T}_{2}$ plants positive for Cry1Ac and GusA (Figure 2), although

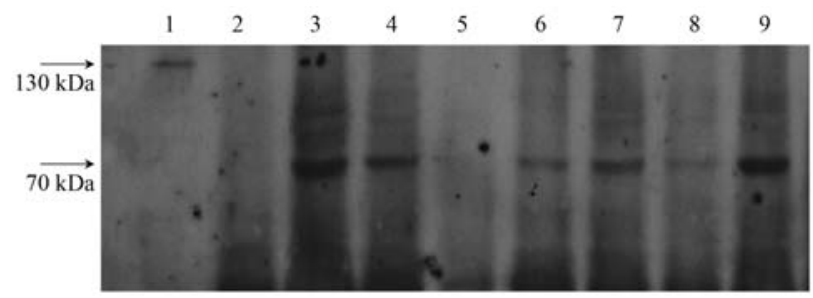

Figure 1 - Detection of recombinant Cry1Ac protein in soybean plants by western blot hybridization. Samples from $\mathrm{T}_{0}$ plants positive for cry $1 A c$ and gus $A$ are shown in lanes 3, 4, 6, 7, 8, 9 of the blot, along with a Bacillus thuringiensis $(B t)$ Cry1Ac protoxin from as positive control (lane 1) and material from non-transgenic soybean cultivar IAS5 (lane 2). Lane 5 was loaded with protein extract from a plant negative for $c r y 1 A c$ but positive for gusA. Arrows indicate the position of the Cryl Ac toxin at $\sim 70 \mathrm{kDa}$ and the Cry1Ac protoxin at $\sim 130 \mathrm{kDa}$.
PCR was also performed on plants which were negative for CrylAc and GusA and the absence of bands suggested that no transgenes could be detected in these plants. The correlation between the presence of transgene DNA and its expression was perfect.

Based on the $48 \mathrm{~T}_{1}$ plants evaluated, it appeared that crylAc plus gus A and hpt were linked at one integration site in the initial $\mathrm{T}_{0}$ plants (Table 2). The $\mathrm{T}_{1}$ progenies of both $\mathrm{T}_{0}$ plants segregated fewer plants positive for cryl Ac and gusA than the 3:1 transgenic to non-transgenic progeny predicted by Mendelian principles for a single dominant locus. The $\mathrm{T}_{2}$ and $\mathrm{T}_{3}$ families continued to segregate in an unusual manner, with a large deficiency of transgenic plants (Table 3). Moreover, the segregation ratios indicated that $T_{2}$ plants were uniformly heterozygous for the transformed traits.

Transgenes are generally expected to behave as dominant genes and segregate in a 3:1 ratio for transgenic to non-transgenic progeny when the plant is self-pollinated, because the transgene locus is considered to be hemizygous in the primary $\left(\mathrm{T}_{0}\right)$ transformant (Campbell et al., 2000). However, transgenic loci introduced into higher plant species frequently display unpredictable patterns of inheritance and expression, which has occurred at a frequency between $10 \%$ and $50 \%$ for some transgenic lines (Yin et al., 2004). Unusual segregation ratios could result from a number of factors, including inactivation of transgene expression, insertion leading to a lethal mutation and poor transgene transmission to the progeny. The inactivation of expression is frequently observed when transgenes are present in multiple copies and is responsible for causing abnormal segregation (Yin et al., 2004). However, our PCR amplifications performed on $\mathrm{T}_{1}$ and $\mathrm{T}_{2}$ plants phenotypically negative for Cry1Ac and GusA confirmed the absence of transgene-DNA in these plants so the inactivation of transgene expression cannot be the reason for the non-Mendelian segregation observed in our study.

The integration of foreign DNA into a plant genome can produce an insertion mutation in an essential gene. A lethal mutation reflected by the lack of homozygotes can lead to a 2:1 segregation for transgenic and non-transgenic traits in the progeny of a transgenic plant. Limanton-Grevet and Jullien (2001) attributed the 2:1 segregation observed

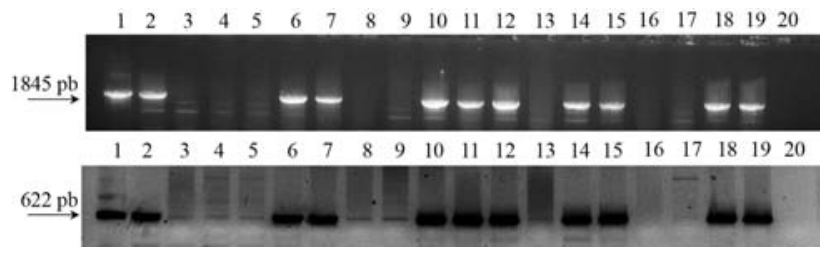

Figure 2 - Polymerase chain reaction amplification of crylAc (A) and gusA (B) from a sample of $\mathrm{T}_{2}$ progeny from the $18 \mathrm{a} 4$ family. Lanes: $1=$ positive control (pGEM4Z/pGusHyg plasmids); 2, 6, 7, 10, 11, 12, 14, 15, 18, 19 = plants positive for Cry1Ac and GusA; 3, 4, 5, 8, 9, 13, 16, $17=$ plants negative for Cry1Ac and GusA; and $20=$ negative control non-transgenic soybean cultivar IAS5. 
Table 2 - Segregation of the $\mathrm{T}_{1}$ generation obtained from the $\mathrm{T}_{0}$ generation of transgenic soybean plants positive for the Bacillus thuringiensis endotoxin gene $\operatorname{cry} 1 A c$ and the $\beta$-glucuronidase reporter gene gusA. The segregation ratios for $\operatorname{cry} l A c$ and gus $A$ were tested using the chi-square test.

\begin{tabular}{|c|c|c|c|c|c|}
\hline \multirow[t]{2}{*}{$\mathrm{T}_{0}$ family } & \multicolumn{5}{|c|}{$T_{1}$ generation (number of plants) } \\
\hline & cry $^{+}$gus $^{+}$ & cry'gus' & cry $^{+}$gus $^{+} /$cry gus & Ratio tested & $\mathrm{p}$ \\
\hline \multirow[t]{2}{*}{ 18a1 } & 2 & 8 & 0.25 & $3: 1$ & $<0.001$ \\
\hline & & & & $2: 1$ & 0.001 \\
\hline \multirow[t]{2}{*}{$18 \mathrm{a} 4$} & 5 & 33 & 0.15 & $3: 1$ & $<0.001$ \\
\hline & & & & $2: 1$ & $<0.001$ \\
\hline
\end{tabular}

Table 3 - Segregation of the $T_{2}$ and $T_{3}$ generations obtained, respectively, from the $T_{1}$ and $T_{2}$ families of transgenic soybean plants positive for the Bacillus thuringiensis endotoxin gene crylAc and the $\beta$-glucuronidase reporter gene gusA. The segregation ratios for the two genes were tested using the chi-square test.

\begin{tabular}{|c|c|c|c|c|c|c|}
\hline \multirow[t]{2}{*}{$\mathrm{T}_{1}$ family } & \multicolumn{6}{|c|}{$\mathrm{T}_{2}$ generation (number of plants) } \\
\hline & cry $^{+} \mathrm{gus}^{+}$ & cry'gus ${ }^{-}$ & cry gus $^{+}$ & cry $^{+}$gus $^{+} /$cry gus $^{-}$ & Ratio tested & $\mathrm{p}$ \\
\hline \multirow[t]{2}{*}{ 18a1 } & 20 & 90 & 1 & 0.22 & $3: 1$ & $<0.001$ \\
\hline & & & & & $2: 1$ & $<0.001$ \\
\hline \multirow[t]{2}{*}{$18 \mathrm{a} 4$} & 81 & 207 & 1 & 0.39 & $3: 1$ & $<0.001$ \\
\hline & & & & & $2: 1$ & $<0.001$ \\
\hline $\mathrm{T}_{2}$ family & \multicolumn{6}{|c|}{$\mathrm{T}_{3}$ generation (number of plants) } \\
\hline \multirow[t]{2}{*}{$18 \mathrm{a} 1$} & 80 & 248 & 0 & 0.32 & $3: 1$ & $<0.001$ \\
\hline & & & & & $2: 1$ & $<0.001$ \\
\hline \multirow[t]{2}{*}{$18 \mathrm{a} 4$} & 229 & 760 & 1 & 0.30 & $3: 1$ & $<0.001$ \\
\hline & & & & & $2: 1$ & $<0.001$ \\
\hline
\end{tabular}

in a $\mathrm{T}_{2}$ progeny of a transformed Asparagus officinalis line to the absence of homozygotes, but since our results did not fit even a 2:1 segregation pattern (Tables 2 and 3) it appears that other factors could be acting. However, non-Mendelian segregation of transgenes could be due to failure of transmittance from one of the gametes. Christou et al. (1989) credited a 1:1 segregation ratio observed in progeny derived from selfing a transgenic soybean plant to the failure to pass a transgene to the next generation through pollen. Feldmann et al. (1997) reported that reciprocal backcrosses to non-transgenic Arabidopsis plants showed unequal gametic transmission of the kanamycin-resistance $\left(\mathrm{Kan}^{\mathrm{R}}\right)$ trait in seven lines for up to six successive generations, two of the lines failing to transmit $\mathrm{Kan}^{\mathrm{R}}$ through the ovule and the extreme $\mathrm{Kan}^{\mathrm{R}}$ deficiency of seedlings of the other five lines being primarily due to failure to transmit the trait through the pollen.

We investigated gametic transgene transmission by crossing several of our transgenic soybean plants with non-transgenic soybean plants. The segregation of the gusA and $c r y 1 A c$ genes in the $\mathrm{F} 1$ backcross $\left(\mathrm{BCF}_{1}\right)$ was determined histochemically for Gus and by double-sandwich ELISA for Cry1Ac. Our results showed transgene transmission through male and female gametes, but at a substantially reduced rate (Table 4 ). In the $18 \mathrm{a} 1$ family, transmission of the transgenes through the pollen was reduced to $60 \%$ to $75 \%$ of that expected for a heterozygote while trans- mission through the ovule dropped to $33 \%$ to $49 \%$. Family $18 \mathrm{a} 4$ displayed a similar transmission rate $(30 \%$ to $47 \%)$ through the ovule, no crosses being made in which the transformant served as the pollen donor. The low number of crosses in which the transformant served as the pollen donor did not allow us to conclude unequivocally that the transmission through pollen was affected less severely than transmission through the ovule.

\section{Homozygous plants positive for both Cry1Ac and GusA}

A $18 \mathrm{a} 4$ family $\mathrm{T}_{3}$ transformant that served as the female parent in the backcross set four seeds which resulted in four plants positive for both CrylAc and GusA, thus indicating that this $\mathrm{T}_{3}$ transformant plant was homozygous. To check this we tested 20 seeds obtained from self-pollination of that plant which we germinated to produce seedlings which showed Gus activity and expressed Cry1Ac, confirming that the plant was homozygous. Based on this fact, we decided to use the same methodology, and the same number (20) of selfed seeds for each plant, to investigate the possible homozygous nature of another 253 out of the $309 \mathrm{~T}_{3}$ transgenic plants which were positive for both Cry1Ac and GusA. Besides the plant already mentioned, our analyses detected a further 12 homozygous $\mathrm{T}_{3}$ plants positive for both Cry1 Ac and GusA. These experiments excluded the possibility of a lethal insertional mutation as a 
Table 4 - Segregation in the $\mathrm{F}_{1}$ backcross $\left(\mathrm{BCF}_{1}\right)$ between transgenic soybean plants positive for the Bacillus thuringiensis endotoxin gene $c r y 1 A c$ plus the $\beta$-glucuronidase reporter gene gusA and non-transgenic soybean cultivar IAS5. In family 18a4, 41 plants were positive for crylAc and gus $A$ but the expected number was $88(41+135 / 2)$ to $135(41 / 135$ to $41 / 88 \approx 30$ to 47$)$. The expected percentages were calculated according to Feldmann et al. (1997).

\begin{tabular}{|c|c|c|c|c|c|c|}
\hline \multirow[t]{4}{*}{ Family } & \multicolumn{6}{|c|}{ Observed segregation (number of plants) } \\
\hline & \multicolumn{4}{|c|}{ Transformant as: } & \multicolumn{2}{|c|}{$\begin{array}{l}\text { Expected percentage of plants positive for } c r y 1 A c \text { and } g u s A \text { when a } \\
c r y l \mathrm{Ac}^{+} \text {and } g u s A^{+} \text {heterozygote is used as: }\end{array}$} \\
\hline & \multicolumn{2}{|c|}{ Pollen donor } & \multicolumn{2}{|c|}{ Pollen recipient } & \multirow[t]{2}{*}{ Pollen donor to cultivar IAS5 } & \multirow[t]{2}{*}{ Pollen recipient from cultivar IAS5 } \\
\hline & cry $^{+}$gus $^{+}$ & cry'gus & cry $^{+}$gus $^{+}$ & cry'gus & & \\
\hline $18 \mathrm{a} 1$ & 9 & 15 & 15 & 46 & 60 to 75 & 33 to 49 \\
\hline $18 \mathrm{a} 4$ & & & 41 & 135 & & 30 to 47 \\
\hline
\end{tabular}

reason for the observed non-Mendelian segregation, because such an occurance would have been reflected by a lack of homozygotes. On the other hand, we assumed that the difficulty in obtaining homozygous plants in the $\mathrm{T}_{2}$ generation could be accounted for the poor transmission of transgenes through pollen and, more importantly, female gametes.

\section{Southern analysis of transformed plants}

Genomic DNA of $T_{1}, T_{2}$ and $T_{3}$ plants positive for Cry $1 \mathrm{Ac}$ and GusA was digested with KpnI, an enzyme that cuts plasmid pGEM4Z only once, SalI that does not cleave the transformation plasmid and Bam HI which releases the $2.1 \mathrm{~kb}$ cry $1 A c$ cassette gene coding region and nos terminator. A representative Southern blot of seven $\mathrm{T}_{1}$ plants (derived from 18a1 and 18a4 $\mathrm{T}_{0}$ plants) positive for Cry1 Ac and GusA is shown in Figure 3. The detection of a $2.1 \mathrm{~kb}$ band in the DNA digested with $B a m H I$ in all plants indicated the presence of at least one intact copy of $c r y 1 A c$. The presence of bands larger than $2.1 \mathrm{~kb}$ is evidence for rearrangements of the transgene DNA. Analysis of digests with $K p n I$ revealed three $c r y l A c$ fragments in all plants. Analysis with SalI confirmed the presence of three copies for that gene (data not shown). Southern blot was also performed on plants negative for Cry1 Ac and GusA in order to determine if transgenes were present but the absence of any hy-

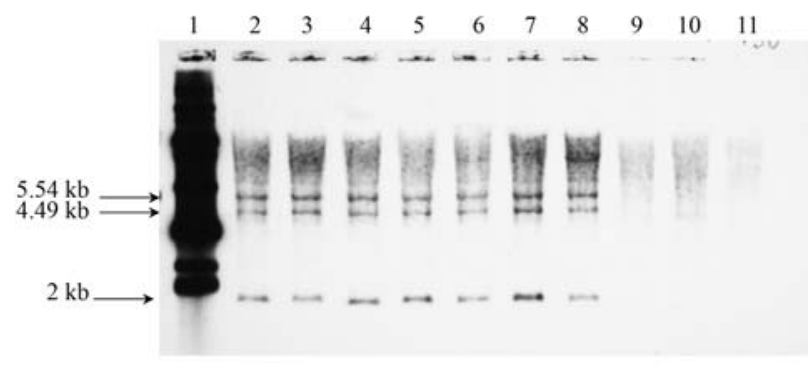

Figure 3 - Southern blot hybridization analysis of the $T_{1}$ progeny of 18a1 and $18 \mathrm{a} 4 \mathrm{~T}_{0}$ plants. Ten $\mu \mathrm{g}$ of genomic DNA was digested with BamHI, separated by electrophoresis in a $0.8 \%$ agarose gel, blotted onto nitrocellulose and hybridized to a $1.8 \mathrm{~kb}$ cry $1 \mathrm{Ac}$ probe. Lanes: $1=$ positive control (pGEM4Z); 2, $3=18 \mathrm{a} 1$ family plants positive for Cry1 Ac and GusA; $4,5,6,7,8=18 \mathrm{a} 4$ family plants positive for Cry1Ac and GusA; and $11=$ negative control non-transgenic soybean cultivar IAS5. bridization signal indicated that these plants probably had no inserted transgene. All the transgenic plants of the $T_{1}, T_{2}$ and $\mathrm{T}_{3}$ progenies analyzed showed the same hybridization pattern as the two $\mathrm{T}_{0}$ parental plants (data not shown) and consequently the same copy number. These results indicate that all copies of the gene are inherited as a unit and that the original transgene integration pattern observed in the primary regenerated plants was stably passed on to all progeny plants.

\section{Insecticidal activity}

To confirm that the Cry1Ac protein produced in the transgenic plants was functional isolated leaves from transgenic plants and non-transgenic control plants were infested with neonate larvae of $A$. gemmatalis. All control leaves were completely defoliated after $24 \mathrm{~h}$ (Figure 4a) but consumption was significantly reduced in transgenic leaves (Table 5; Figure 4b) and, in comparison to larvae fed on control leaves, larvae fed on transgenic leaves showed browning and severe growth retardation (Figure 4c). In these experiments any remaining leaf tissue was remove $24 \mathrm{~h}$ after the start of feeding and replaced with a normal laboratory diet. Within $48 \mathrm{~h}$ larvae initially fed on transgenic leaves stopped feeding and most were dead, with only two or less (depending on the replicate) surviving for $96 \mathrm{~h}$. However, 19 out of 20 larvae reared on control leaves sur-

Table 5 - Bioassay of the insecticidal activity of $T_{2}$ transgenic soybean plants expressing the Bacillus thuringiensis Cry1Ac endotoxin. Twenty Anticarsia gemmatalis neonate larva were placed onto a detached leaf and the percentage leaf consumption estimated $24 \mathrm{~h}$ later and converted to a score: $0=$ no consumption, $1=$ less than $50 \% ; 2=$ more than $50 \%$; and $3=100 \%$ consumption. After $24 \mathrm{~h}$ any remaining leaf tissue was removed and replaced by a piece of a solid artificial diet and the mean number of live larva recorded at $48 \mathrm{~h}$ and $96 \mathrm{~h}$. Non-transgenic soybean cultivar IAS5 with no gene for the Cry1Ac endotoxin was used as the control.

\begin{tabular}{lccc}
\hline \multirow{2}{*}{$\begin{array}{l}\text { T } \\
\text { control plants }\end{array}$} & $\begin{array}{c}\text { Mean leaf } \\
\text { consumption score }\end{array}$ & \multicolumn{2}{c}{ Mean number of live larvae } \\
\cline { 3 - 4 } & $24 \mathrm{~h}$ & $48 \mathrm{~h}$ & $96 \mathrm{~h}$ \\
\hline $18 \mathrm{a} 1$ & 1.25 & 3.68 & 1.75 \\
$18 \mathrm{a} 4$ & 1.40 & 4.02 & 1.95 \\
IAS5 control & 3.00 & 19.92 & 19.33 \\
\hline
\end{tabular}




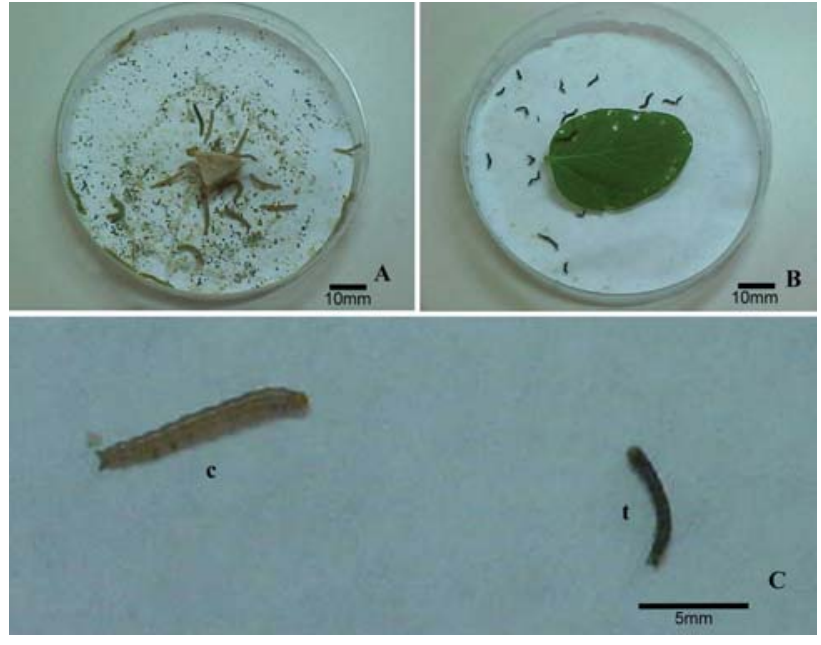

Figure 4 - Insect bioassay. Defoliation of control non-transgenic soybean cultivar IAS5 (A) and transgenic (B) leaves $24 \mathrm{~h}$ after infestation with Anticarsia gemmatalis larvae. (C) Larva fed on a transgenic leaf showing browning and severe growth retardation $(t)$ in comparison to larva fed on a control leaf (c).

vived for $96 \mathrm{~h}$. The mortality of $A$. gemmatalis affected by expression of $c r y l A c$ in transgenic leaves of plants from the $18 \mathrm{a} 1$ and the $18 \mathrm{a} 4$ families was similar. This data could be accounted for the fact that both families were derived from the same transformation event. Soybean cultivars containing $B$. thuringiensis (Bt) toxin gents ('Bt soybeans') have not yet been commercialized, although experimental lines have been developed. Parrott et al. (1994) reported that the expression of a native $c r y l A b$ gene prevented the feeding and growth of $A$. gemmatalis larvae. It has been reported that a transgenic line of the soybean cultivar Jack expressing high levels of synthetic crylAc killed all A. gemmatalis larvae and significantly reduced the survival and feeding of the soybean looper (Pseudoplusia includens) and the corn earworm (Helicoverpa zea) in laboratory bioassays (Stewart et al., 1996) and in artificially infested field cages (Walker et al., 2000). More recently, Macrae et al. (2005) evaluated transgenic soybean lines (based on cultivar A5547) expressing synthetic crylA for resistance against several lepidopteran pests in screenhouse and conventional field trials carried out in the United States and Argentina and found that the $B t$ lines exhibited virtually complete efficacy against all the pests evaluated.

\section{Intralocus recombination}

Co-transformation is one of the best strategies to obtain marker-free transgenic plants since it is based on the principle that a proportion of transformed plants carrying the selectable marker gene will also have integrated the transgene of interest at a second, unlinked, insertion site and the genes can subsequently be removed from such plants by genetic segregation (Ebinuma et al., 2001; Bettany et al., 2002; Park et al., 2004). We used this cotransformation strategy to introduce $\mathrm{cryl} A \mathrm{c}$ into soybean

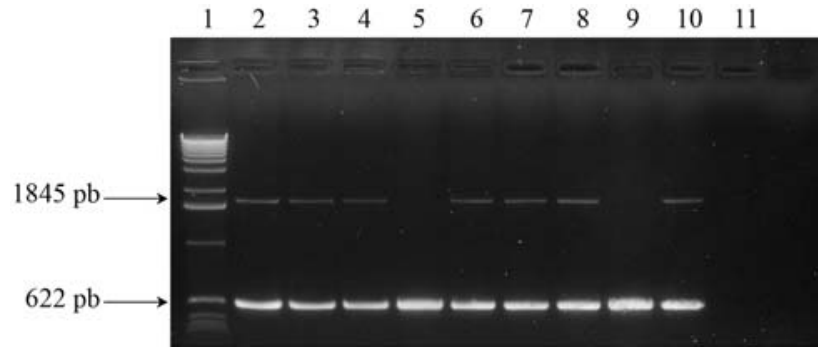

Figure 5 - Polymerase chain reaction amplification of cry $1 A c$ and gus $A$ from a sample of $18 \mathrm{a} 1 \mathrm{~T}_{2}$ progeny. Lanes: $1=1 \mathrm{~kb}$ ladder; $2=$ positive control (pGEM4Z/pGusHyg plasmids); 3, 4, 6, 7, 8, $10=$ plants positive for Cry1 Ac and GusA; 5, $9=$ plants negative for Cry1 Ac but positive for GusA; and 11 = negative control non-transgenic soybean cultivar IAS5.

with the expectation of obtaining marker-free transgenic plants. However, as the co-transformed crylAc, gusA and $h p t$ integrated at a single locus they segregated together. A high incidence of linkage has been demonstrated when using biolistic-mediated co-transformation (Miki and McHugh, 2004) but, nevertheless, we still obtained three transgenic plants negative for Cry1Ac but positive for GusA (Table 3; Figure 5), perhaps because interchromosomal recombination split up the transgenes. It is possible that the transgenic locus contains interspersed genomic DNA within it (Kohli et al., 2003). Intriguingly, up to now, no plants containing the $\mathrm{cry} 1 \mathrm{Ac}$ gene alone have been obtained.

In this paper we have outlined the success development of A. gemmatalis-resistant transgenic soybean (cultivar IAS5) plants containing synthetic crylAc. Although the segregation was non-Mendelian in the first generations our data clearly demonstrated that the transgenes were stably transmitted and expressed in progenies. Homozygous transgenic plants were obtained in the $\mathrm{T}_{3}$ generation and the agronomic performance and the response of these plants toward field populations of A. gemmatalis are under analysis. Further studies involving combined molecular and cytogenetic analysis can now be performed to determine the transgenic locus organization.

\section{Acknowledgments}

We would like to thank the following people for their important contributions to this study: Dr. Flávio Moscardi (EMBRAPA Soja, Londrina, PR), Dr. José Roberto Salvadori (EMBRAPA Trigo, RS), Dr. Luiz Carlos Federizzi (Departamento de Plantas de Lavoura, UFRGS), Dr. Márcia Pinheiro Margis (Departamento de Genética, UFRGS) and Silvia N. Cordeiro Richter (technical assistance). This work was financially supported by Conselho Nacional de Desenvolvimento Científico e Tecnológico (CNPq, Brazil), Fundação de Amparo à Pesquisa do Estado do Rio Grande do Sul (FAPERGS, Brazil), Centro do Agronegócio-Casa Rural (Brazil), The Rockfeller Foundation (USA) and Natural Sciences and Engineering Research 
Council (NSERC, Canada). Milena S. Homrich acknowledges $\mathrm{CNPq}$ for her Ph.D. fellowship. The authors thank an anonymous reviewer for valuable suggestions.

\section{References}

Bettany AJE, Dalton SJ, Timms E, Dhanoa MS and Morri P (2002) Effect of selectable gene to reporter gene ratio on the frequency of co- transformation and co-expression of uidA and $h p t$ transgenes in protoplast-derived plants of tall fescue. Plant Cell Tissue Organ Cult 68:177-186.

Bradford MM (1976) A rapid and sensitive method for the quantification of microgram quantities of protein utilizing the principle of protein-dye binding. Anal Biochem 72:248-254.

Campbell BT, Baenziger PS, Mitra A, Sato S and Clemente T (2000) Inheritance of multiple transgenes in wheat. Crop Sci 40:1133-1141.

Christou P, Swain WF, Yang NS and McCabe DE (1989) Inheritance and expression of foreign genes in transgenic soybean plants. Genetics 88:7500-7504.

Christou P and Swain WF (1990) Co-transformation frequencies of foreign genes in soybean cell cultures. Theor Appl Genet 79:337-341.

Donaldson PA and Simmonds DH (2000) Susceptibility to Agrobacterium tumefaciens and cotyledonary node transformation in short-season soybean. Plant Cell Rep 19:478-484.

Doyle JJ and Doyle JL (1987) A rapid DNA isolation procedure for small quantities of fresh leaf tissues. Phytochem Bull 19:11-15.

Droste A, Pasquali G and Bodanese-Zanettini MH (2002) Transgenic fertile plants of soybean [Glycine max (L.) Merrill] obtained from bombarded embryogenic tissue. Euphytica 127:367-376

Ebinuma H, Sugita K, Matsunaga E, Endo S, Yamada K and Komamine A (2001) Systems for the removal of a selection marker and their combination with a positive marker. Plant Cell Rep 20:383-392.

Feldmann KA, Coury DA and Christianson ML (1997) Exceptional segregation of a selectable marker $\left(\operatorname{Kan}^{\mathrm{R}}\right)$ in Arabidopsis identifies genes important for gametophytic growth and development. Genetics 147:1411-22.

Finer JJ and McMullen MD (1991) Transformation of soybean via particle bombardment of embryogenic suspension culture tissue. In Vitro Cell Dev Biol-Plant 27:175-182.

Finer JJ, Vain P, Jones MW and McMullen MD (1992) Development of the particle inflow gun for DNA delivery to plant cells. Plant Cell Rep 11:323-328.

Gamborg OL, Miller RA and Ojima K (1968) Nutrient requirements of suspension cultures of soybean root cells. Exp Cell Res 50:151-158.

Greene GL, Leppla NC and Dickerson WA (1976) Velvet bean caterpillar: A rearing procedure and artificial medium. J Econ Entomol 69:487-488.

Hofmann N, Nelson RL and Korban SS (2004) Influence of media components and $\mathrm{pH}$ on somatic embryo induction in three genotypes of soybean. Plant Cell Tissue Organ Cult 77:157-163.

Jefferson RA (1987) Assaying chimeric genes in plants: The Gus gene fusion system. Plant Mol Biol Rep 5:387-405.

Ko TS, Nelson RL and Korban SS (2004) Screening multiple soybean cultivars (MG 00 to MG VIII) for somatic embryo- genesis following Agrobacterium-mediated transformation of immature cotyledons. Crop Sci 44:1825-1831.

Kohli A, Twyman RM, Abranches R, Wegel E, Stoger E and Christou P (2003) Transgene integration, organization and interaction in plants. Plant Mol Biol 52:247-258.

Li HY, Zhu YM, Chen Q, Conner RL, Ding XD, Li J and Zhang BB (2004) Production of transgenic soybean plants with two anti-fungal protein genes via Agrobacterium and particle bombardment. Biol Plant 48:367-374.

Limanton-Grevet A and Jullien M (2001) Agrobacterium-mediated transformation of Asparagus officinalis L.: Molecular and genetic analysis of transgenic plants. Mol Breed 7:141150.

Macrae TC, Baur ME, Boethel DJ, Fitzpatrick BJ, Gao AG, Gamundi JC, Harrison LA, Kabuye VT, Mcpherson RM, Miklos JA et al. (2005) Laboratory and field evaluations of transgenic soybean exhibiting high-dose expression of a synthetic Bacillus thuringiensis crylA gene for control of Lepidoptera. J Econ Entomol 98:577-587.

McCabe DE, Swain WF, Martinell BJ and Christou P (1988) Stable transformation of soybean (Glycine max) by particle acceleration. Bio/Technol 6:923-926.

Meurer CA, Dinkins RD, Redmond CT, McAllister KP, Tucker DT, Walker DR, Parrott WA, Trick HN, Essic JS, Frantz HM et al. (2001) Embryogenic response of multiple soybean [Glycine $\max (\mathrm{L}$.) Merr.] cultivars across three locations. In Vitro Cell Dev Biol-Plant 37:62-67.

Miki B and McHugh S (2004) Selectable marker genes in transgenic plants: Applications, alternatives and biosafety. J Biotechnol 107:193-232.

Murashige T and Skoog F (1962) A revised medium for rapid growth and bioassays with tobacco tissue cultures. Physiol Plant 15:473-497.

Olhoft PM, Flagel LE, Donovan CM and Somers DA (2003) Efficient soybean transformation using hygromycin B selection in the cotyledonary-node method. Planta 216:723-735.

Panizzi AR and Corrêa-Ferreira BS (1997) Dynamics in the insect fauna adaptation to soybean in the tropics. Trends Entomol 1:71-88.

Park J, Lee YK, Kang BK and Chung WI (2004) Co-transformation using a negative selectable marker gene for the production of selectable marker gene-free transgenic plants. Theor Appl Genet 109:1562-1567.

Parrott WA, Hoffman LM, Hildebrand DF, Williams EG and Collins GB (1989) Recovery of primary transformants of soybean. Plant Cell Rep 7:615-617.

Parrott WA, All JN, Adang MJ, Bailey MA, Boerma HR and Stewart CN (1994) Recovery and evaluation of soybean (Glycine max [L.] Merr.) plants transgenic for a Bacillus thuringiensis var. Kurstaki insecticidal gene. In Vitro Cell Dev Biol-Plant 30:144-149.

Paz MM, Martinez JC, Kalvig AB, Fonger TM and Wang K (2006) Improved cotyledonary node method using an alternative explant derived from mature seed for efficient Agrobacterium-mediated soybean transformation. Plant Cell Rep 25:206-213.

Prodromou C and Pearl LH (1992) Recursive PCR - A novel technique for total gene synthesis. Protein Eng 5:827-829.

Sambrook J and Russel DW (2001) Molecular Cloning: A Laboratory Manual. 3rd ed. Cold Spring Harbor, New York. 
Santarém ER, Pelissier B and Finer JJ (1997) Effect of explant orientation, $\mathrm{pH}$, solidifying agent and wounding on initiation of soybean somatic embryos. In Vitro Cell Dev Biol-Plant 33:13-19.

Santarém ER and Finer JJ (1999) Transformation of soybean [Glycine Max (L.)Merrill] using proliferative embryogenic tissue maintained on semi-solid medium. In Vitro Cell Dev Biol-Plant 35:451-455.

Santos KGB, Mundstock E and Bodanese-Zanettini MH (1997) Genotype-specific normalization of soybean somatic embryogenesis through the use of an ethylene inhibitor. Plant Cell Rep. 16:859-864.

Sardana R, Dukiandjiev S, Giband M, Cheng X, Cowan K, Sauder $\mathrm{C}$ and Altosaar I (1996) Construction and rapid testing of synthetic and modified toxin gene sequences CryIA (b \& c) by expression in maize endosperm culture. Plant Cell Rep 15:677-681.

Stewart CN, Adang MJ, All JN, Boerma HR, Cardineau G, Tucker D and Parrott WA (1996) Genetic transformation, recovery, and characterization of fertile soybean transgenic for a synthetic Bacillus thuringiensis crylAc gene. Plant Physiol 112:121-129.

Trick HN and Finer JJ (1998) Sonication-assisted Agrobacterium-mediated transformation of soybean [Glycine $\max (\mathrm{L}$.) Merrill] embryogenic suspension culture tissue. Plant Cell Rep 17:482-488.
Walker DR, All JN, McPherson RM, Boerma HR and Parrott WA (2000) Field evaluation of soybean engineered with a synthetic crylAc transgene for resistance to corn earworm, soybean looper, velvetbean caterpillar (Lepidoptera, Noctuidae), and lesser cornstalk borer (Lepidoptera, Pyralidae). J Econ Entomol 93:613-622.

Wright MS, Launis KL, Novitzky R, Duesiing JH and Harms CT (1991) A simple method for the recovery of multiple fertile plants from individual somatic embryos of soybean [ Glycine $\max ($ L.) Merrill]. In Vitro Cell Dev Biol-Plant 27:153-157.

Yan B, Reddy MSS, Collins GB and Dinkins RD (2000) Agrobacterium tumefaciens-mediated transformation of soybean [Glycine $\max$ (L.) Merrill.] using immature zygotic cotyledon explants. Plant Cell Rep 19:1090-1097.

Yin Z, Plader W and Malepszy S (2004) Transgene inheritance in plants. J Appl Genet 45:127-144.

\section{Internet Resources}

MAPA, Ministério da Agricultura, Pecuária e Abastecimento, http://www.agricultura.gov.br/pls/portal/url/ITEM/ 37AA904436961F63E040A8C07502416D (October 15, 2007).

Associate Editor: Everaldo Gonçalves de Barros

License information: This is an open-access article distributed under the terms of the Creative Commons Attribution License, which permits unrestricted use, distribution, and reproduction in any medium, provided the original work is properly cited. 